\title{
Bedrock Geology of the
}

\section{arompton Quadrangle \\ Rhode Island}

EOLOGY OF SELECTED QUADRANGLES IN RHODE ISLAND ALONZO W. QUINN

E O L O G I A L S U R V E B ULLE T I N 1158-B

repared in cooperation with

ie State of Rhode Island, ovelopment Council

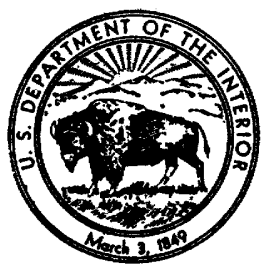


UNITED STATES DEPARTMENT OF THE INTERIOR

STEWART L. UDALL, Secretary

\section{GEOLOGIGAL SURVEY}

Thomas B. Nolan, Director 


\section{CONTENTS}

\begin{tabular}{|c|c|}
\hline & Page \\
\hline & Abstract \\
\hline Introduction $_{-}$ & 1 \\
\hline ratigraphic units & 2 \\
\hline Blackstone Series & 2 \\
\hline Westboro Quartzite & 3 \\
\hline Sneech Pond Schist. & 3 \\
\hline Amphibole schist & 3 \\
\hline Serpentine & 4 \\
\hline Fine-grained gneiss and porphyroblastic gneiss & 4 \\
\hline rocks & 6 \\
\hline Diorite & 6 \\
\hline Scituate Granite Gneiss & 7 \\
\hline Fine-grained granite & 7 \\
\hline Esmond Granite & 8 \\
\hline East Greenwich Group & 8 \\
\hline Spencer Hill Volcanics $\ldots \ldots \ldots$ & 9 \\
\hline Cowesett Granite. & 9 \\
\hline Gray perthitic granite & 10 \\
\hline Pennsylvanian sedimentary rocks of the Narragansett basin & 11 \\
\hline Pondville Conglomerate & 11 \\
\hline Rhode Island Formation & 12 \\
\hline Mafic dikess & 12 \\
\hline Mafic dike at Andrews Hill & 13 \\
\hline Mafic dike at Hungry Hill & 13 \\
\hline ology & 13 \\
\hline Metamorphism & 14 \\
\hline Engineering and economic geology & 15 \\
\hline 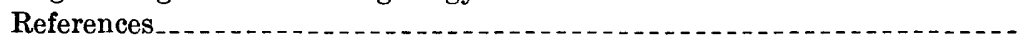 & 16 \\
\hline
\end{tabular}

\section{ILLUSTRATIONS}

Plate 1. Bedrock geologic map and sections of the Crompton quadrangle, Rhode Island..... In pocket 



\title{
GEOLOGY OF SELECTED QUADRANGLES IN RHODE ISLAND
}

\section{BEDROGK GEOLOGY OF THE CROMPTON QUADRANGLE, RHODE ISLAND}

\author{
By Alonzo W. Quins
}

\begin{abstract}
In the Crompton quadrangle the oldest rocks are the Precambrian(?) Blackstone Series, which includes the Westboro Quartzite and the Sneech Pond Schist. These metamorphic rocks are exposed chiefly in the northeastern part of the quadrangle. Possibly equivalent are fine-grained gneiss and porphyroblastic gneiss in the southwestern part.

Plutonic rocks of Mississippian(?) or older age are intrusive into the older rocks. These include diorite, Scituate Granite Gneiss, fine-grained granite, and Esmond Granite. The Scituate Granite Gneiss underlies most of the quadrangle.

The East Greenwich Group of Mississippian(?) age includes Spencer Hill Volcanics, Cowesett Granite, and gray perthitic granite, which are exposed in the eastern part of the quadrangle.

A very small part of the Narragansett basin of Pennsylvanian sedimentary rocks extends into the quadrangle from the east. Included are the Pondville Conglomerate and the Rhode Island Formation. These rocks are unconformable on the older plutonic and metamorphic rocks and are assigned to the Pennsylvanian System on the basis of plant fossils discovered in several parts of the basin. The Pennsylvanian rocks here have been affected by metamorphism of sufficient intensity to produce muscovite, biotite, and garnet.
\end{abstract}

Possibly the youngest rocks are mafic dikes exposed in road cuts in the southern part of the quadrangle.

\section{INTRODUCTION}

The present report on the bedrock geology of the Crompton quadrangle is one of a series of reports describing the bedrock geology and the surficial geology of Rhode Island. These geological studies are a cooperative project of the Rhode Island Development Council and the U.S. Geological Survey.

Topographically and geologically Rhode Island is divided into two areas, an eastern one-third and a western two-thirds. The eastern onethird is part of a topographic lowland which includes Narragansett Bay. Geologically it is a structural basin, the Narragansett basin of Pennsylvanian sedimentary rocks. The western two-thirds of the 
State is an upland underlain almost entirely by plutonic and metamorphic rocks that are older than the Pennsylvanian rocks of the Narragansett basin. The Crompton quadrangle, at the margin of the Narragansett basin, is underlain by pre-Pennsylvanian rocks, except for very small areas of Pennsylvanian rocks along the east margin of the quadrangle. (See pl. 1.)

\section{STRATIGRAPHIC UNITS}

The Crompton quadrangle is underlain chiefly by granites and granite gneisses and also in small areas by Blackstone Series, mostly in the northeast part of the quadrangle, fine-grained gneiss, diorite, Spencer Hill Volcanics at the east margin, Pennsylvanian sedimentary rocks, and mafic dikes. The Blackstone Series of Precambrian(?) age includes the Westboro Quartzite and amphibole schist and serpentine equivalent in age to the Sneech Pond Schist. The fine-grained gneiss, which appears to be an inclusion or a relict in the Scituate Granite Gneiss, may be either a granitized part of the Blackstone Series or it may be part of some formation not otherwise exposed in the Crompton quadrangle. The granites and granite gneiss include the Scituate Granite Gneiss of Mississippian( ?) or older age, fine-grained granite probably related to the Scituate Granite Gneiss, the Esmond Granite of Mississippian (?) or older age, the Cowesett Granite of Mississippian(?) age, and gray perthitic granite probably related to the Cowesett Granite. The few small areas of diorite may be related either to the Blackstone Series or to the granitic rocks. The Pennsylvanian rocks include the Pondville Conglomerate and a very small area of the Rhode Island Formation. The mafic dikes are probably of Pennsylvanian or later age.

\section{BLACKSTONE SERIES}

The Blackstone Series was originally described from exposures in the valley of the Blackstone River in the Pawtucket quadrangle approximately 15 miles north of the Crompton quadrangle (Shaler, Woodworth, and Foerste, 1899, p. 104-109). This series includes a large variety of metamorphosed sedimentary and igneous rocks (Quinn, Ray, and others, 1948; Quinn, Ray, and Seymour, 1949). It has been divided into the Mussey Brook Schist, the overlying Westboro Quartzite, the Sneech Pond Schist which overlies the quartzite, and the Hunting Hill Greenstone, which includes various intrusive and extrusive rocks scattered through the other formations of the Blackstone Series. The Blackstone Series has been assigned a Precambrian(?) age, but the evidence is indirect, and a Paleozoic age may yet be established (Quinn, Ray, and others, 1948, p. 9-10). 
The Blackstone Series was intruded by several different igneous rocks in such a manner that the series is now exposed as isolated areas surrounded by intrusive rocks. The area near the northeast corner of the Crompton quadrangle appears to be such an isolated area of metamorphic rocks, but the eastern part is covered by the Pennsylvanian sedimentary rocks of the Narragansett basin. The thick quartzite of the Crompton quadrangle is correlated with the Westboro Quartzite on the basis of similar lithologic character, and the overlying amphibole schist is correlated with the Sneech Pond Schist because of similarity of stratigraphic position. Small bodies of serpentine similar to that in the Crompton quadrangle have been discovered at various stratigraphic positions within the Blackstone Series elsewhere.

\section{WESTBORO QUARTZITE}

The Westboro Quartzite underlies the northeast slopes of Natick Hill and extends northward across the Pawtuxet River, where it is abundantly exposed on the bluffs and slopes north of the river. Four large inclusions of the quartzite occur in the Cowesett Granite south and west of the main area of the quartzite. The quartzite generally strikes approximately east and dips northward. The eastward trend carries it into the East Greenwich quadrangle and to the margin of the Narragansett basin, where it is overlain unconformably by the Pennsylvanian sedimentary rocks of the basin.

The quartzite is chiefly light gray medium grained massive quartzite consisting predominantly of quartz in interlocking grains, but containing also small amounts of biotite, muscovite, and chlorite, along with accessory garnet, tourmaline, clinozoisite, pyrite, and zircon. Interbedded with the quartzite are many layers of gray to brown quartz-mica schist that contains large amounts of biotite and muscovite, in addition to quartz and accessory minerals. The beds of quartz-mica schist range from a few inches to a few feet thick. The inclusion of quartzite at Centerville contains a layer of conglomerate.

\section{SNEECH POND SCHIST}

AMPHIBOLE SCHIST

Amphibole schist is exposed north of the North Branch of the Pawtuxet River along the east margin of the quadrangle. The amphibole schist is mostly dark gray, but some is light gray. Most of it is medium grained, schistose, and thin bedded. Amphibole, biotite, quartz, and oligoclase are the main constituents; the dark minerals are predominant only in certain layers. Minor and accessory constituents, some of which are abundant locally, include epidote, chlorite, magnetite, ilmenite, garnet, sphene, and rutile. Some layers 
are chlorite schist and a few contain an abundance of epidote. In places they are contorted and cut by many small stringers of granite, pegmatite, and vein quartz, all apparently related to the Esmond Granite.

The amphibole schist strikes approximately east, parallel to the Westboro Quartzite; it overlies the quartzite with apparent conformity and in turn is overlain by the Pondville Conglomerate. The schist is correlated tentatively with the Sneech Pond Schist, which overlies the Westboro Quartzite in the Pawtucket quadrangle (Quinn, Ray, and others, 1948; Quinn, Ray, and Seymour, 1949) and in the Providence quadrangle (Quinn, 1959). The same correlation was suggested for the continuation of the schist into the East Greenwich quadrangle to the east (Quinn, 1952). The schist was intruded by the serpentine and later was intruded by the Esmond Granite. Therefore, the schist is older than the serpentine, the Esmond Granite, and the Pondville Conglomerate and is younger than the Westboro Quartzite. Along with the rest of the Blackstone Series, it is assigned a Precambrian (?) age.

The width of outcrop and the dips of the amphibole schist indicate that its thickness here is 2,500 to 3,000 feet. Very little folding that might invalidate this estimate of thickness has been observed.

\section{SERPENTINE}

Serpentine is exposed on both sides of Phenix Avenue near the northeast corner of the quadrangle. The fresh serpentine is medium gray, greenish, and dark gray; weathered serpentine is light gray to medium gray. This rock is fine to medium grained massive to schistose serpentine containing relicts of olivine. Magnetite is common and a carbonate mineral is common locally. Pyrite is a minor constituent; in places, talc is abundant and the rock has a greasy feel.

As in the Pawtucket quadrangle (Quinn, Ray, and others, 1948, p. 13; and Quinn, Ray, and Seymour, 194'J), the serpentine is enclosed partly by rocks of the Blackstone Series. The serpentine is intruded into the Blackstone Series and it seems to have been affected by the same metamorphism. The parent rock of the serpentine was probably a small intrusive of ultramafic rock, which was serpentinized soon after intrusion or during the metamorphism of the Blackstone Series. The serpentine is truncated by the Esmond Granite on the west.

\section{FINE-GRAINED GNEISS AND PORPHYROBLASTIC GNEISS}

Fine-grained gneiss, in part porphyroblastic, is exposed in road cuts at the southeast end of Hungry Hill. The gneiss is light gray, fine grained, and moderately gneissic. Parts of it have an abundance of 
large porphyroblasts of microcline microperthite, mostly alined with the foliation. Typical fine-grained nonporphyroblastic gneiss has the following mineral composition: quartz 34 percent, microcline and microperthite 31 percent, oligoclase $\left(\mathrm{An}_{18}\right) 28$ percent, biotite 6 percent, and accessory minerals 1 percent. The accessory minerals include allanite, magnetite, zircon, apatite, and a carbonate mineral. Two modal analyses of the matrix of porphyroblastic gneiss gave the following mineral compositions (in the same order) : quartz 28 and 31 percent, microcline and microperthite 36 and 23 percent, oligoclase 28 and 36 percent, biotite 5 and 9 percent, amphibole 2 percent and absent, accessories 1 percent. Accessories includes allanite, sphene, magnetite, zircon, and apatite.

Porphyroblasts make up about 17 percent of the rock, and therefore the whole rock has approximately the following composition: microcline and microperthite 39 percent, plagioclase 28 percent, quartz 25 percent, biotite 6 percent, amphibole 1 percent, and accessory minerals 1 percent.

These road cuts at the southeast end of Hungry Hill show clearly the relations of the fine-grained gneiss to the porphyroblastic gneiss and to the Scituate Granite Gneiss. The porphyroblastic gneiss is part of the fine-grained gneiss that has had the porphyroblasts added to it or formed in it; all gradations are shown between these two gneisses.

The Scituate Granite Gneiss is intrusive into the other gneisses. Some of the contacts are sharp and in places the Scituate seems to show flow structure parallel to the contact. The structural relations seem to indicate that the Scituate Granite Gneiss was emplaced here in a liquid state, with blocks of the other gneisses included. The porphyroblasts may have been derived from the Scituate Granite Gneiss, but evidence opposed to this is the fact that many small inclusions within the Scituate, a foot or less across, have no porphyroblasts. Therefore, it appears that the fine-grained gneiss was made variably porphyroblastic and that the Scituate Granite Gneiss was intruded subsequently into both the nonporphyroblastic and the porphyroblastic types.

The age of the fine-grained and the porphyroblastic gneisses is unknown, except that they are older than the Scituate Granite Gneiss. Other bodies of metamorphic rocks are enclosed by the Scituate Granite Gneiss and by other gneissic rocks at many places in western and southwestern Rhode Island (Moore, 1958, 1959; Nichols, 1956). These bodies of metamorphic rocks may be inclusions, roof pendants, or relicts. Many of them have been correlated with the Blackstone Series on the basis of lithologic similarity or proximity to larger bodies of known Blackstone Series. Such a correlation is herein made for the 
metamorphic rocks near Centerville. Much less certain is the correlation of the fine grained gneiss and the porphyroblastic gneiss of Hungry Hill. This place is about 6 miles from the nearest exposed Blackstone Series, at Natick Hill, and there is no marked similarity to the rocks most common in the Blackstone Series. There seems to be no sound basis for deciding, whether these rocks are part of the Blackstone Series or are part of some formation not elsewhere exposed in this area.

\section{PLUTONIC ROCKS}

Most of the large bodies of intrusive rocks in Rhode Island have been assigned to a Devonian or older, or Devonian(?) or older age, both on the basis of geologic relations and on such age determinations as were available. Included in this assignment were the Scituate Granite Gneiss and related rocks, the Esmond Granite, the Grant Mills Granodiorite, and several diorites and quartz diorites. The interpretation of geological relationships remains the same, but recent age determinations appear to demand some revision of the geologic time scale (Faul, 1960). For example, the mean age, 306 million years, of the Scituate Granite Gneiss (Quinn, Jaffe, and others, 1957) would place it in the Mississippian or the Pennsylvanian of Faul's proposed time scale, rather than in the Devonian as believed formerly. It is probable that many new age determinations will be forthcoming and that further modification of the geologic time scale will be necessary. Therefore, these plutonic rocks of Rhode Island cannot now be given definite geologic ages, but are indicated as Mississippian(?) or as Mississippian (?) or older.

\section{DIORITE}

A small diorite mass of Mississippian(?) or older age is exposed on a hill in Westcott and in several dikes on the north bank of the Pawtuxet River.

The diorite is rather variable, with the color ranging from light gray to dark gray, the texture from fine to medium grained, and the structure from massive to streaky and schistose. The chief minerals are amphibole, biotite, oligoclase, and quartz, but these vary in their relative proportions. Minor and accessory constituents include epidote, chlorite, microperthite, sphene, apatite, magnetite, and zircon.

The diorite intruded the Westboro Quartzite, but its relations to other rocks are not known. Small granitic dikes and other irregular intrusions cut the diorite; this granitic material may be a late facies of the diorite or it may be related to some of the later granites, such as the nearby Cowesett Granite. The diorite here, like that in the Pawtucket quadrangle (Quinn, Ray, and others, 1948; Quinn, Ray, and Seymour, 1949), may have been intruded almost contemporaneously 
with the Hunting Hill Greenstone of the Blackstone Series, or it may be considerably later and more closely affiliated with other plutonic rocks such as the Esmond Granite.

\section{SCITUATE GRANITE GNEISS}

The Scituate Granite Gneiss of Mississippian ( ?) or older age underlies by far the greatest part of the Crompton quadrangle, and also large parts of nearby quadrangles. Extensive exposures may be seen around Carr Pond, in the road cuts at the southeast end of Hungry Hill, north of Harkney Hill Road at the west margin of the quadrangle, near the northwest corner of the quadrangle, and on the hill northwest of the intersection of Flat River Road and Read School Road.

In most places the Scituate Granite Gneiss is light pink, although locally it is gray. It is coarse to medium grained, and oval splotches of biotite give the rock a gneissic lineation or foliation. The chief constituents are pink microcline and microperthite, white or gray albite-oligoclase, quartz, dark greenish to dark brownish-green biotite, and green hornblende. The minor and accessory constituents identified are chlorite, muscovite, zircon, allanite, magnetite, ilmenite, pyrite, fluorite, sphene (or keilhauite; see Young, 1938), apatite, and monazite. Biotite and the accessory minerals are commonly grouped together in clusters. Sixteen modal analyses gave the following results: potassium feldspar 34 to 57 percent, averaging 45 percent; albite-oligoclase 1 to 22 percent, averaging 10 percent; quartz 31 to 58 percent, averaging 40 percent; biotite 1 to 8 percent, averaging 4 percent; accessory minerals 1 percent.

The Scituate Granite Gneiss was named from extensive exposures in the North Scituate quadrangle to the north (Quinn, 1951). Exposures in the Crompton quadrangle show that the Scituate Granite Gneiss is younger than the gneisses at the south end of Hungry Hill and older than the mafic dike at the same locality and older than the fine-grained granite. In nearby areas the Scituate Granite Gneiss is seen to be younger than the Blackstone Series and older than the Esmond Granite (Quinn, 1951), the Cowesett Granite (Quinn, 1952), and the Pennsylvanian rocks of the Narragansett basin. Age determinations by the lead-alpha method gave 306 million years as the average of the Scituate Granite Gneiss and affiliated rocks (Quinn, Jaffe, and others, 1957).

\section{FINE-GRAINED GRANITE}

Near the north margin of the quadrangle west of North Branch Pawtuxet River is a body of fine-grained granite of Mississippian( ?) or older age; it is approximately $11 / 2$ miles long and a quarter of a mile 
wide. This is intrusive into the Scituate Granite Gneiss and is similar to fine-grained granite of the North Scituate quadrangle, except that there the rock is more porphyritic (Quinn, 1951).

The rock is light pink to tan, fine to medium grained, somewhat porphyritic locally, and massive to weakly foliated. The main constituents are microperthite, albite, quartz, and biotite; the biotite is in small clusters. Minor constituents and accessory minerals include chlorite, magnetite, allanite, and zircon. One modal analysis gave the following results: microperthite 42 percent, albite 15 percent, quartz 36 percent, biotite 5 percent, and accessory minerals 2 percent.

\section{ESMOND GRANITE}

The Esmond Granite of Mississippian(?) or older age underlies a small area at the northeast corner of the Crompton quadrangle; this is continuous with Esmond Granite in the North Scituate, the Providence, and the East Greenwich quadrangles. Other small bodies are intrusive into the amphibole schist near the Providence-Kent County line at the east margin of the quadrangle.

The Esmond Granite is light pink to light flesh colored, medium grained, and massive to somewhat foliated. The chief minerals are microperthite and microcline, albite, quartz, and biotite. The albite apparently is the result of the alteration of a more calcic plagioclase to albite, sericite, and epidote. Much of the biotite has been altered to chlorite. Other constituents include muscovite, magnetite, apatite, and garnet.

The Esmond Granite is clearly intrusive into the amphibole schist and into the serpentine of the Blackstone Series. The relation of the Esmond Granite to the Scituate Granite Gneiss was not observed in the Crompton quadrangle, but in the North Scituate quadrangle the Esmond Granite was found to be younger (Quinn, 1951). Similarly, the relation of the Esmond Granite to the Cowesett Granite was not determined in the Crompton quadrangle, but in the East Greenwich quadrangle the Cowesett is the younger. The Pennsylvanian Pondville Conglomerate is known definitely to be younger than the Esmond Granite, because at the east margin of the quadrangle, the conglomerate was observed to contain boulders of the Esmond Granite.

\section{EAST GREENWICH GROUP}

The East Greenwich Group includes volcanic rocks, shallow intrusive rocks, and the Cowesett Granite, all well exposed in the East Greenwich quadrangle (Quinn, 1952). The Cowesett Granite extends a considerable distance and the Spencer Hill Volcanics extend a short distance into the Crompton quadrangle. In addition, a gray 
perthitic granite is exposed in the Crompton quadrangle and is assigned tentatively to this group.

\section{SPENCER HHL VOLCANICS}

The Spencer Hill Volcanics of the East Greenwich Group are exposed in road cuts on Quaker Lane at the east margin of the quadrangle, 1300 feet north of Greenwich Avenue. These rocks are much more abundantly exposed in the East Greenwich quadrangle to the east (Quinn, 1952). Included in this formation are rhyolite flows, volcanic breccia, and some conglomerate. The conglomerate is well exposed at the road cut on Quaker Lane. There the boulders are as much as a foot long, but most are a few inches long. Most of the boulders and pebbles are felsite, but many are quartzite and many are granite. The rhyolite flows and the breccia are not much exposed in the Crompton quadrangle.

Relationships of the Spencer Hill Volcanics have been determined from exposures in the East Greenwich quadrangle. There the volcanic rocks are younger than the Esmond Granite and older than the Cowesett Granite (Quinn, 1952). This implies a considerable age difference between the Esmond Granite and the Cowesett Granite. The volcanic rocks and the Cowesett Granite are probably of almost the same age and are considered to be Mississippian(?).

\section{COWESETT GRANITE}

The Cowesett Granite underlies an area along the east margin of the quadrangle southward from Natick Hill. The most abundant exposures are on the southern slopes of Natick Hill and within about a mile of the southeast corner of the quadrangle.

The rock is light pink to flesh colored, medium grained, commonly subporphyritic, and massive. Megascopically the rock consists of pink to tan feldspars, quartz, and biotite in small clusters. Locally the rock is brown as a result of weathering. The main constituents identified in thin section are microcline, microperthite, albite, quartz, and dark-green biotite. Minor and accessory constituents include chlorite, muscovite, magnetite, sphene, fluorite, zircon, and allanite. Four modal analyses gave the following proportions: potassium feldspar 42 to 53 percent, averaging 50 percent; albite 2 to 19 percent, averaging 8 percent; quartz 36 to 39 percent, averaging 37 percent; biotite 1 to 6 percent, averaging 4 percent; and accessory minerals 1 percent.

Exposures in the Crompton quadrangle show that the Cowesett Granite is younger than the Westboro Quartzite of the Blackstone Series. Intrusive relations with the Westboro Quartzite are well exposed at several places on Natick Hill, and four large inclusions of 
quartzite are exposed on the southern slopes of the hill and in Centerville. The granite-quartzite contacts are sharp and some inclusions of quartzite appear to have been rotated within the granite. To the east in the East Greenwich quadrangle this granite intruded the Spencer Hill Volcanics and it was overlain unconformably by the Pennsylvanian sedimentary rocks of the Narragansett basin (Quinn, 1952). The granite, together with the other rocks of the East Greenwich Group, is correlated tentatively with the Quincy Granite of Massachusetts and affiliated rocks of Mississippian(?) age (Quinn, 1952). The bases for this correlation are (1) its geologic age, younger than the Scituate Granite Gneiss and older than the Pennsylvanian sedimentary rocks, (2) the similar associations of plutonic, shallow intrusive, and extrusive rocks, and (3) a mean age of 267 million years on three sizes of zircon from the Cowesett Granite of the East Greenwich quadrangle (Quinn, Jaffe, and others, 1957).

\section{GRAY PERTHITIC GRANITE}

Granite of uncertain relationships is exposed in two areas: (1) from Jackson at the north to Crompton at the south, an area approximately 4 miles long and 11/2 miles wide, and (2) near Andrews Hill, an area about $11 / 2$ miles long and a little less than a mile wide. Although this rock is well exposed in both of these areas, its relations to the Cowesett Granite and especially to the Scituate Granite Gneiss are not shown at many places.

The fresh granite is gray, but is tan or brown where weathered. It is coarse to medium grained, subporphyritic with some phenocrysts as much as $10 \mathrm{~mm}$ long, and with oval masses of biotite as much as $15 \mathrm{~mm}$ long. These oval bodies of biotite give the rock a foliation in many places. The main constituents are glassy feldspar, quartz, and biotite; purple fluorite is prominent at many outcrops, especially in the vicinity of Andrews Hill. The main constituents are microcline microperthite, quartz, and very dark green biotite. Typically the microperthite is in rather larger irregular Carlsbad twins in a matrix of medium-sized to small quartz grains. Most of the albite is contained within the microperthite, although in places separate grains of albite form as much as 9 percent of the rock. Generally this rock differs from the Cowesett Granite and from the Scituate Granite Gneiss by having almost all of the plagioclase within the microperthite and almost none of it as separate grains. The biotite is commonly grouped with the accessory minerals into oval clusters. The minor and accessory minerals identified include chlorite, muscovite, magnetite, pyrite, fluorite, zircon, sphene, allanite, apatite, and garnet. Riebeckite is an important constituent in (1) a small aban- 
doned quarry a quarter of a mile north of Lippitt and (2) exposures a quarter of a mile southeast of Lippitt just north of the railroad. At these two places the riebeckite is both in average-sized grains of the granite and in larger crystals in small pegmatites. Seventeen modal analyses gave the following proportions: Potassium feldspar 40 to 59 percent, averaging 49 percent; quartz 36 to 50 percent, averaging 43 percent; albite 0 to 9 percent, averaging 2 percent; biotite 2 to 8 percent, averaging 5 percent; and accessory minerals 1 percent.

The gray perthitic granite is correlated tentatively with the Cowesett Granite, although the coarse texture and the splotchy arrangement of the biotite are more like the Scituate Granite Gneiss. The only contact exposed is on a long ledge 1,200 feet south of the West Greenwich-East Greenwich line and 2,200 feet west of the east margin of the quadrangle. Here the Cowesett Granite grades into the gray perthitic granite, the gradation consisting of the increase in abundance of microperthite phenocrysts of the Cowesett Granite to the extent that the rock has the coarse texture of the gray perthitic granite. Other evidences for correlating with the Cowesett Granite are indirect. They include the texture (Carlsbad twins of microperthite in groundmass of quartz), the presence of riebeckite, and the presence of purple fluorite. All these are characteristic of the Quincy Granite as exposed in the Pawtucket quadrangle (Quinn, Ray, and others, 1948; Quinn, Ray, and Seymour, 1949) and in the vicinity of Quincy, Mass.

\section{PENNSYLVANIAN SEDIMENTARY ROCKS OF THE NARRAGANSETT BASIN}

\section{PONDVILLE CONGLOMERATE}

Only a very small part of the Narragansett basin of Pennsylvanian sedimentary rocks extends from the East Greenwich quadrangle into the Crompton quadrangle and this is at a point about $1 \frac{1}{2}$ miles south of the north border. Most of the exposed rock here is Pondville Conglomerate, but some of the Rhode Island Formation also extends into the Crompton quadrangle.

The Pondville Conglomerate is chiefly light-gray to gray conglomerate, but it includes also many interbeds of gray sandstone and graywacke. Some boulders in the conglomerate are as much as 2 feet long. The bedding is unusually variable and irregular, owing both to the original character of the bedding and to later deformation. The boulders and cobbles are predominantly quartzite that appears to be identical to Westboro Quartzite exposed nearby. Very few boulders or cobbles of the amphibole schist have been found in the conglomerate. 


\section{B12 GEOLOGY OF SELECTED QUADRANGLES, RHODE ISLAND}

There are a few boulders of the Esmond Granite in the conglomerate where it lies directly on the granite. A few sandstone interbeds consist almost entirely of disintegrated debris of the granite, and, owing to recrystallization by metamorphism, they are almost exactly like the granite, except that they show bedding. Most of the boulders and cobbles are angular, but some are rounded; in most places they show a rude lineation with the longest dimensions plunging $30^{\circ}$ to $40^{\circ} \mathrm{NE}$. Metamorphism, which shows a progressive increase in the Narragansett basin to the south and southwest, was intense enough here to cause the formation of garnet, muscovite, and biotite in the matrix of the conglomerate and in the sandstone.

Approximately 500 feet west of the margin of the Narragansett basin is a small outlier of the Pondville Conglomerate. This outlier, which is a tight syncline, is one of the very few outliers associated with the Narragansett basin. The pebbles here are somewhat elongated; their longest dimensions trend almost north and horizontal, apparently parallel to the axis of the syncline.

The Pondville Conglomerate is at the base of the Narragansett basin and in the Crompton quadrangle is about 160 feet thick (Quinn, 1952).

\section{RHODE ISLAND FORMATION}

In the East Greenwich quadrangle to the east are large exposures of gray sandstone and graywacke of the Rhode Island Formation (Quinn, 1952), which lies directly above the Pondville Conglomerate. The Rhode Island Formation is the thickest and the most extensively exposed formation of the Narragansett basin, but it barely extends into the Crompton quadrangle.

\section{MAFIC DIKES}

Two mafic dikes were exposed in the road cuts made along a new highway north of Division Street in 1957 and 1958; neither had been exposed in natural outcrops. One is at the north end of Andrews Hill and the other is near the southeast end of Hungry Hill. In the dike at Andrews Hill the augite is comparatively fresh and the other minerals are greatly altered. In the other dike the labradorite is comparatively fresh and the other minerals are much altered. Both dikes may have been diabase or olivine diabase, but the dikes are so much altered that determination of their original character is not possible.

There is little evidence concerning the age of the dikes. That at Andrews Hill intruded the gray perthitic granite and that at Hungry Hill intruded the Scituate Granite Gneiss and the fine-grained gneiss. Although both dikes were somewhat altered, both also contain unaltered minerals, so it appears that they were not involved in 
metamorphism. This probably means that they were intruded after the Pennsylvanian or Permian metamorphism of the Pennsylvanian rocks of the Narragansett basin about 4 miles east of Andrews Hill.

\section{MAFIC DIKE AT ANDREWS HITL}

The dike at the north end of Andrews Hill is about 2 feet thick; it strikes $\mathrm{N} .25^{\circ} \mathrm{W}$., and it dips $80^{\circ} \mathrm{W}$.

This rock is dark gray to black, fine grained, and massive. The rock is considerably altered; titaniferous augite alone is relatively fresh. Plagioclase appears to have been the most abundant constituent, but most of it has been altered to sericite. A few unaltered remnants are labradorite $\left(\mathrm{An}_{55}\right)$. Much of the rest of the rock is composed of the alteration minerals biotite, chlorite, and talc and a carbonate mineral. A few patches of alteration have the shapes of olivine crystals, but no unaltered olivine was seen. Magnetite and ilmenite are common. The rock is probably altered diabase or olivine diabase.

\section{MAFIC DIKI AT HUNGRY HILC}

The dike rock at Hungry Hill is almost black, very fine grained, and massive. It consists of labradorite $\left(\mathrm{An}_{66}\right)$ in a very fine matrix. A few small grains of augite and some magnetite were identified as original constituents of the matrix, much of which has been altered to biotite, chlorite, a carbonate mineral, and talc. Some areas of alteration minerals have the shapes of olivine phenocrysts, but no olivine was identified. The rock contains a few small amygdules filled with a carbonate mineral and very fine radial aggregates of unidentified minerals.

The dike is shown on the map as a single dike several hundred feet long. It is exposed at four places in the road cuts. At the northernmost exposure there are two branches of the dike, each branch about a foot thick and the branches are separated by about 2 feet of gneiss. The greatest thickness exposed is about 4 feet. The trends at the different exposures suggest that the dike either changes its strike or is in segments offset from each other. At the northernmost exposure the dikes are almost vertical and in the middle the single dike dips $63^{\circ} \mathrm{W}$.

\section{STRUCTURAL GEOLOGY}

The rocks of the Blackstone Series are part of a larger mass that extends from the East Greenwich quadrangle into the Crompton quadrangle. In most of this mass of rocks the bedding and the foliation strike approximately east and dip moderately to the north, with the Westboro Quartzite on the south dipping under the younger am- 
phibole schist to the north. Small folds are not abundant, although they may be seen in some outcrops.

The fine-grained gneiss and the porphyroblastic gneiss have consistently steep dips and north-northwest trends of the foliation.

The diorite is commonly streaky and foliated parallel to its contacts. The Scituate Granite Gneiss is foliated or lineated, or both, at most outcrops. The lineation plunges north throughout the quadrangle. The foliation trends in various directions, but within most small areas the trends are almost the same. Foliation in the finegrained granite is commonly parallel to the contact with the Scituate Granite Gneiss. Exposures of the Esmond are too few to reveal its structure, but it cuts discordantly across the Blackstone Series. Foliation in the gray perthitic granite is commonly parallel to that of the nearby Scituate Granite Gneiss. The Cowesett Granite is commonly massive and without foliation or lineation. It cuts discordantly across the Blackstone Series and the Spencer Hill Volcanics.

A prominent structural feature of the East Greenwich quadrangle is the marked angular unconformity between the Pennsylvanian sedimentary rocks of the Narragansett basin and the underlying older rocks. This unconformity barely extends into the Crompton quadrangle, but the unconformable relationship may be observed along the part of the contact that is present in the Crompton quadrangle. Furthermore, boulders of the Esmond Granite may be seen in the Pondville Conglomerate at the margin of the quadrangle. The body of Pondville Conglomerate that lies approximately 500 feet west of the Narragansett basin is a synclinal outlier. Both the outlier and the main contact are offset by a small fault.

\section{METAMORPHISM}

At least two episodes of metamorphism affected the general area that includes the Crompton quadrangle. The first metamorphism occurred after the deposition of the Blackstone Series and before or partly during the intrusion of the Scituate Granite Gneiss. The second major episode of metamorphism happened after the deposition of the Pennsylvanian sedimentary rocks of the Narragansett basin.

The metamorphism of the Blackstone Series caused nearly pure quartz sandstone to recrystallize as Westboro Quartzite and more shaly interbeds to recrystallize as quartz-mica schist layers in the Westboro Quartzite. The amphibole schist overlying the Westboro Quartzite probably was originally mafic volcanic rock or calcareous shale. This recrystallized during metamorphism chiefly to dark bluish-green amphibole, biotite, oligoclase, and quartz, with also some chlorite, epidote, garnet, and several accessory minerals. The mineral composition indicates an intensity of metamorphism corresponding to the 
almandine amphibolite facies (Fyfe, Turner, and Verhoogen, 1958, p. 228). Most of the foliation in the Blackstone Series was developed parallel to the bedding.

The Scituate Granite Gneiss shows distinct foliation or lineation at most places. Evidence at the road cut at the southeast end of Hungry Hill and elsewhere (Quinn, 1951) indicates that the gneiss was intruded as a magma and that the foliation is a flow structure. However, there are wide areas where the structure of the gneiss is of indeterminate origin; it may be flow structure, relict structure, or a later metamorphic structure imposed upon the rock. The character of the foliation is indeterminate in much of the Crompton quadrangle. Evidence supporting origin by a later metamorphism is the near parallelism of trends of the Scituate Granite Gneiss, the gray perthitic granite, and the Cowesett Granite near Andrews Hill and eastward. This evidence is not very conclusive, as exposures are widely spaced. This possible metamorphism would have had to occur after the formation of the Cowesett Granite and before the deposition of the Pondville Conglomerate. Moore (1958) and Power (1959) described evidence of a post-Scituate metamorphism in the Hope Valley quadrangle and in the Slocum quadrangle, respectively.

The Esmond Granite was affected by a metamorphism of low intensity that caused a more calcic plagioclase to alter to albite with many tiny inclusions of epidote and muscovite. This may have been an alteration during the cooling of the granite.

The Cowesett Granite and the gray perthitic granite show no important effects of metamorphism, except in association with local shearing. The Cowesett Granite was the cause of some feldspathization of the Blackstone Series in the vicinity of Natick Hill, more notably in the East Greenwich quadrangle (Quinn, 1952).

The Pennsylvanian sedimentary rocks of the Narragansett basin show the results of metamorphism that increased in intensity from the north to the south (Quinn and Glass, 1958). This intensity was sufficient to produce biotite, muscovite, and garnet at the small exposures of Pennsylvanian rocks in the Crompton quadrangle. It also caused the elongation of boulders in the Pondville Conglomerate and the interlocking of quartz grains in the sandstone.

\section{ENGINEERING AND ECONOMIC GEOLOGY}

The rocks of the Crompton quadrangle have yielded little of economic value. A few small quarries for dimension stone were opened in the Scituate Granite Gneiss near the north end of Carr Pond, just west of Read School Road, about half a mile west of Arkwright, 11/2 miles west of Arkwright, and just south of Washington. These 
quarries are now abandoned. As almost all the bedrock is strong and hard where fresh, it is suitable for foundations and will stand in deep excavations. However, at several places the granitic rocks have been weathered to "rottenstone." This disintegration, which is chiefly physical, renders the rock so soft that it can be dug with a shovel. In most places the weathering extends no more than 10 or 15 feet below the surface. One area of weathered Scituate Granite Gneiss is just east and south of Pine Swamp near the north margin of the quadrangle. Weathered Scituate Granite Gneiss is also exposed near the intersection of Colvintown Road and Station Street. A wide area of weathered gray perthitic granite extends half a mile both north and south of Harris. Another area of weathered gray perthitic granite is in the vicinity of West Warwick, Quidnick, and Arctic. These areas are of economic importance, both because the bedrock there is not strong and because this weathered rock is used locally for driveways and other surfaces intended for light traffic.

Gravel and sand which are of considerable economic importance here, have been described in a report on the surficial geology of the area (Smith, 1956). Ground water is another resource of economic importance here and it, too, was described in another report (Allen, Johnson, and Mason, 1959).

\section{REFERENCES}

Allen, W. B., Johnson, K. E., and Mason, R. A., 1959, Ground-water map of the Crompton quadrangle, Rhode Island: R.I. Water Resources Coordinating Board, GWM 3.

Faul, Henry, 1960, Geologic time scale: Geol. Soc. America Bull., v. 71, p. 637-644.

Fyfe, W. S., Turner, F. J., and Verhoogen, J., 1958, Metamorphic reactions and metamorphic facies : Geol. Soc. America Mem. 73, 259 p.

Moore, G. E., Jr., 1958, Bedrock geology of the Hope Valley quadrangle, Rhode Island : U.S. Geol. Survey Geol. Quad. Map GQ-105.

1959, Bedrock geology of the Carolina and Quonochontaug quadrangles, Rhode Island : U.S. Geol. Survey Geol. Quad. Map GQ-117.

Nichols, D. R., 1956, Bedrock geology of the Narragansett Pier quadrangle, Rhode Island : U.S. Geol. Survey Geol. Quad. Map GQ-91.

Power, Walter R., Jr., 1959, Bedrock geology of the Slocum quadrangle, Rhode Island: U.S. Geol. Survey Geol. Quad. Map GQ-114.

Quinn, A. W., 1951, Bedrock geology of the North Scituate quadrangle, Rhode Island : U.S. Geol. Survey Geol. Quad. Map GQ-13.

1952, Bedrock geology of the East Greenwich quadrangle, Rhode Island: U.S. Geol. Survey Geol. Quad. Map GQ-17.

1959, Bedrock geology of the Providence quadrangle, Rhode Island: U.S. Geol. Survey Geol. Quad. Map GQ-118.

Quinn, A. W., and Glass, H. D., 1958, Rank of coal and metamorphic grade of rocks of the Narragansett basin of Rhode Island: Econ. Geology, v. 53, p. 563-576. 
Quinn, A. W., Jaffe, H. W., Smith, W. L., and Waring, C. L., 1957, Lead-alpha ages of Rhode Island granitic rocks compared to their geologic ages: Am. Jour. Sci., v. 255, p. 547-560.

Quinn, A. W., Ray, R. G., and Seymour, W. L., 1949, Bedrock geology of the Pawtucket quadrangle, Rhode Island-Massachusetts: U.S. Geol. Survey Geol. Quad. Map GQ-1.

Quinn, A. W., Ray, R. G., Seymour, W. L., Chute, N. E., and Allen, W. B., 1948, Geology and ground-water resources of the Pawtucket quadrangle, Rhode Island : R.I. Industrial Comm., Geol. Bull. 3, 85 p.

Shaler, N. S., Woodworth, J. B., and Foerste, A. F., 1899, Geology of the Narragansett basin : U.S. Geol. Survey Mon. 33, 402 p.

Smith, J. H., 1956, Surflcial geology of the Crompton quadrangle, Rhode Island : U.S. Geol. Survey Geol. Quad. Map GQ-94.

Young, J. A., Jr., 1938, Keilhauite, a guide mineral to the Sterling granite gneiss of Rhode Island: Am. Mineralogist, v. 23, p. 149-152. 


